
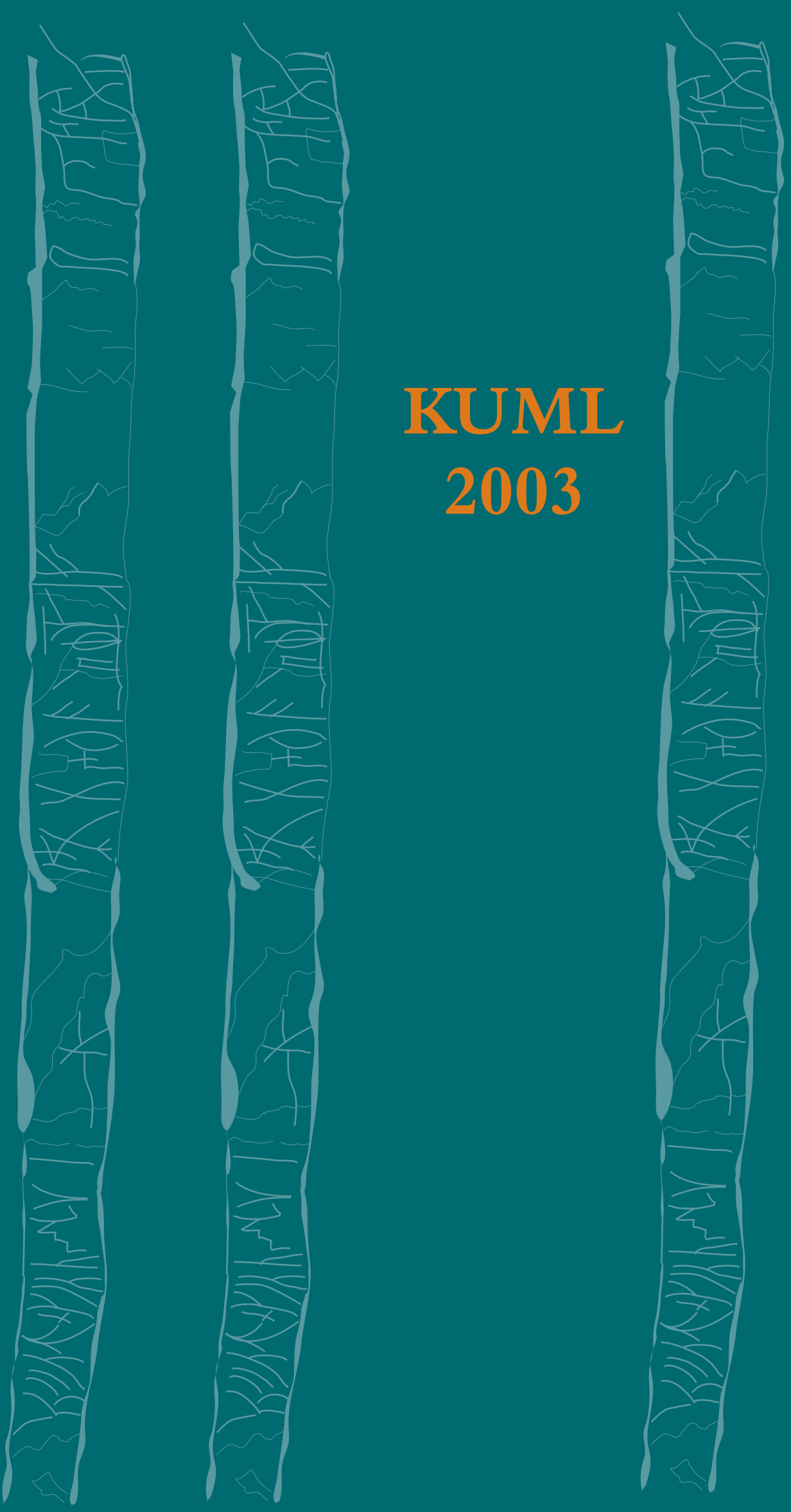


\section{KUML 2003}

Årbog for Jysk Arkæologisk Selskab

With summaries in English

I kommission hos Aarhus Universitetsforlag 


\title{
Høje, landskab og bosættelse Rekognosceringer ved Tobøl-Plougstrup-højgruppen
}

\author{
Af STEFFEN TERP LAURSEN, KASPER LAMBERT JOHANSEN, \\ MADS KÄHLER HOLST OG MARIANNE RASMUSSEN
}

Ved Tobøl-Plougstrup i Jernved og Føvling sogne, Ribe amt har en højgruppe bestående af 26 gravhøje i næsten 150 år med mellemrum tiltrukket sig stor arkæologisk opmærksomhed. Højgruppen er beliggende på den flade smeltevandsslette ved Kongeåens nordside og afgrænses på alle sider af vådområder med små sidebække til Kongeåen. Ni høje er fredede, mens de resterende i dag ligger i dyrket mark og helt eller delvist er forsvundet.

Rige gravfund med blandt andet store guldspiralringe og fuldgrebssværd vidner om, at området i ældre bronzealder havde en særlig karakter. Derudover er højene markant større end det normale for denne type monumenter. Det viser, at begravelsesritualernes omfang i form af den arbejdsindsats, der ligger bag højbyggeriet, også har været ekstraordinær. De største høje er placeret ved kanten af den eroderede engbrink, så de har fremstået tydeligt ved sejlads på Kongeåen og fra områderne mod syd. ${ }^{1}$

Fundene af velbevarede egekistebegravelser i tre høje inden for højgruppen er imidlertid det, der først og fremmest har tiltrukket sig opmærksomhed. Den første egekiste fremkom i 1860 ved usagkyndiges afgravning af Fladshøj og findes nu på Nationalmuseet. I 1896 under udgravning af Sortehøj afdækkede A.P. Madsen endnu en kiste, der i dag opbevares på Den antikvariske Samling i Ribe. Den sidst fundne egekiste er fra Storehøj. Her havde Carl Neergaard i 1893 afdækket en tom grav centralt i højen, men den velbevarede egekiste fremkom først i 1950 under muldafgravning af højtomten. Det varede yderligere 10 år, inden fundstedet blev fagligt efterundersøgt af Henrik Thrane, og på det tidspunkt var egekisten forgået. På trods af de uheldige omstændigheder kan fundet delvist rekonstrueres og tolkes som resterne af en egekistebegravelse med spektakulært udstyr. Fundet indeholdt blandt andet en guldspiralring og et unikt bronzehjul lidt større end de velkendte fra Solvognen. ${ }^{2}$

I 1999 blev højgruppen ved Tobøl-Plougstrup igen genstand for undersøgelser. I forbindelse med et større forskningsprojekt blev der foretaget boringer i samtlige tilbageværende, overpløjede og fredede gravhøje. For- 
målet var at skaffe oplysninger om højenes konstruktion, jordbundsforholdene både i selve højfylden og i den jordbund, som højene var opført på, samt at få klarhed over højenes bevaringsforhold. ${ }^{3}$

Boringerne afslørede flere høje med kraftige jernlagsudfældninger omkring højkernen. Det er disse jernlag, som igennem en fastholden af et vandmættet miljø i højens midte er forudsætningen for de enestående bevaringsforhold, der kendes fra de berømte egekistebegravelser. Nye undersøgelser af jernlagene tyder på, at de afspejler en særlig højkonstruktion eller specielle aktiviteter i forbindelse med højkonstruktionen. ${ }^{4}$ Det peger endnu en gang i retning af, at højgruppen ved Tobøl-Plougstrup har indtaget en speciel rolle i det bronzealderlige samfund. Samtidig forklarer det områdets bemærkelsesværdige koncentration af de ellers meget sjældne egekistefund.

Fokus i forbindelse med de gode bevaringsforhold i jernlagshøjene har traditionelt været rettet kraftigt mod selve begravelsen, men de giver også en lang række forbedrede analytiske muligheder i forhold til højfylden. Vegetationen på de tørv, højene er bygget af, kan stadig bestemmes, og det miljø, som højene indgik i, kan rekonstrueres usædvanligt detaljeret. I højgruppens almindelige høje kan de samme forhold belyses, men med noget mindre detaljeringsgrad. Jordbundsanalyser af højfylden kan eksempelvis give udsagn om dyrkningsintensitet, udvaskning og generelle træk ved vegetationen på arealerne omkring højene i tiden før højkonstruktionen. Prøver udtaget fra højfylden kan endvidere levere materiale til C14datering af højopførelsestidspunkterne. Med de mange punkter fordelt over tid inden for et snævert rum er der således mulighed for at tegne et nuanceret billede af en landskabsudnyttelse gennem et længere tidsrum.

Den sydlige del af Ribe amt hører til blandt de forholdsvis velundersøgte områder med hensyn til bopladser fra samme tidsrum som højgruppen, dvs. senneolitikum og ældre bronzealder. Hjortlund og Kalvslund sogne, beliggende umiddelbart syd for Tobøl-Plougstrup, har regionens tæetteste fundkoncentration fra perioden, og det er særligt bopladsfundene, der er velrepræsenterede her. ${ }^{5}$ Betragter man det samlede fundbillede, ses en tendens til en forholdsvis jæevn fordeling af aktivitetsspor langs sydsiden af Kongeåen, mens nordsiden, hvor højgruppen ligger, er bemærkelsesværdig fundtom (fig. 1).

De allerede kendte bopladsfund antyder således en struktur, der forholder sig negativt til højgruppen. Det afgrænsede sletteområde kan under det intensiverede højbyggeri i bronzealderen tænkes at have indtaget en status som en form for lukket, rituelt landskab. Belysningen af, hvordan et sådant rituelt landskab udvikles, forudsætter en forståelse af samspillet mellem høje, landskab og bosættelse: Hvordan påvirkede det omfattende højbyggeri landskabet, hvordan udviklede højgruppen sig i forhold til bosættelsen, og hvilken rolle spillede gravhøjene i den sociale organisation? Besva- 


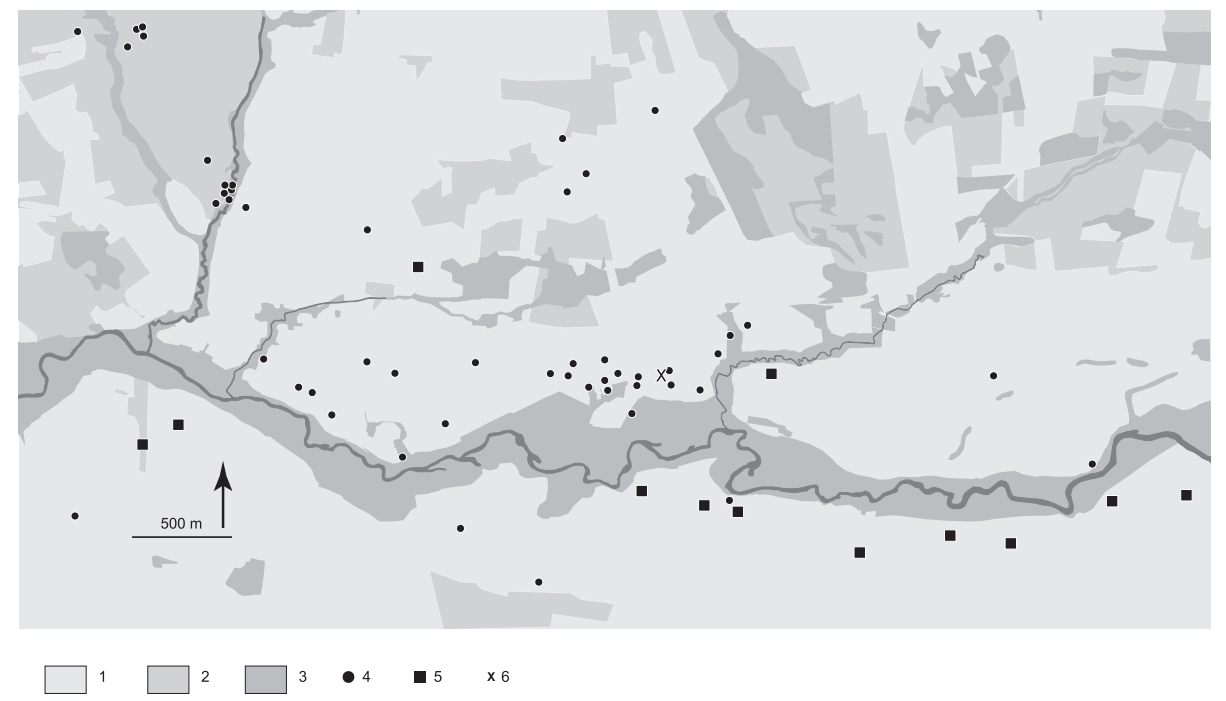

Fig. 1. Fordelingen af gravhøje samt bopladser og enkeltfund fra senneolitikum/ældre bronzealder i området omkring Tobøl-Plougstrup. 1: Tørbund; 2: Hede; 3: Vådbund; 4: Gravhøje; 5: Bopladser; 6: Enkeltfund. Bopladser er defineret ved mere end to genstande daterbare til perioden. Vådbund og hedearealer er sammentegnet fra ældre kortmateriale, målebordsblade og udskiftningskort.

The distribution of prehistoric barrows, sites, and single finds from Late Neolithic/Early Bronze Age in the Tobøl-Plougstrup area. 1: dry land; 2: moor; 3: wetland; 4: barrows; 5: settlement sites; 6: stray finds. Sites are defined by the presence of two or more flint tools datable to the period. The extent of wetland and moor is reconstructed from older cartographical material.

relsen af disse spørgsmål er helt central for forståelsen af bronzealderens samfund, men der er samtidig tale om problemstillinger, som klart skal ses $i$ et større perspektiv såvel tidsmæssigt som rumligt. Forudsætningerne for det bronzealderlige billede i Tobøl-Plougstrup rækker langt tilbage i neolitikum, og højgruppens betydning må sættes i relation til områdets placering i et større kommunikations- og distributionsnetværk. ${ }^{6}$

Tobøl-Plougstrup-områdets særligt gode muligheder for analytisk at bevæge sig fra et detaljeret til et overordnet niveau førte i 1999 til etableringen af et større tværvidenskabeligt forskningsprojekt. Målet er at få indsigt $\mathrm{i}$ den brede vifte af faktorer, der førte frem til det bronzealderlige samfund og landskab ved Kongeåen. Et centralt element i projektet er udgravningen af den fem meter høje Skelhøj inden for perioden 2002-2004. Højen har en jernlagsforseglet kerne med gode bevaringsforhold for organisk materiale og muliggør dermed en detaljeret rekonstruktion af landskabet i højens nærmiljø. Analyser af det bronzealderlige fundmateriale i 
en større region omkring højgruppen forsøger at belyse områdets placering i det bronzealderlige distributionssystem og højgruppens rolle i samfundets overordnede sociale organisation. Endelig er der i 1999 indledt en rekognosceringskampagne i området omkring højgruppen på begge sider af Kongeåen. ${ }^{8}$ Hensigten er at opnå et dækkende billede af bosættelsen og landskabsudnyttelsen forud for og under højbyggeriet, hvilket kræver et rumligt set repræsentativt billede af de forhistoriske aktivitetsspor. Resultaterne af rekognosceringerne kan efterfølgende sammenholdes med de naturvidenskabelige analyser af gravhøjenes fyld, og herigennem er der åbnet mulighed for en vurdering af højgruppens udvikling i forhold til landskab og bosættelse.

Projektets overordnede problemstillinger stiller en række krav til rekognosceringerne først og fremmest med hensyn til systematikken, og valget af en rekognosceringsmetode har derfor spillet en afgørende rolle. Artiklen her præsenterer den valgte metode og dens muligheder på baggrund af opnåede resultater.

\section{Rekognosceringsmetode}

Rekognosceringskampagnen har grundlæggende to formål: For det første at lokalisere regulære bosættelser som ved konventionel rekognoscering, for det andet at indsamle materiale fra området uden for bosættelserne for derigennem at kunne belyse generelle udnyttelsesstrategier i landskabet.

De målsætninger er af stor betydning ved valget af en egnet rekognosceringsmetode. Der er behov for en ensartet, systematisk fremgangsmåde både på og uden for bopladser for at sikre, at det indsamlede materiale er sammenligneligt og velegnet til statistiske analyser. Det skal være muligt at dække et større geografisk område inden for en overskuelig tidsramme. De enkelte indsamlinger skal være lokaliseret forholdsvist præcist. Med mindst mulig indsats skal der skaffes så meget diagnostisk materiale, at karakteren af de enkelte aktivitetsspor kan belyses. Endelig skal den anvendte metode kunne afgrænse fundkoncentrationer.

Konventionel rekognoscering i form af markvandring opfylder ikke kravene. Først og fremmest er det vanskeligt at fastholde formelle retningslinjer for indsamling, og der er i praksis stor variation i fremgangsmåden, alt efter om opsamlingerne foregår på eller uden for bopladser. ${ }^{9}$ Der arbejdes på den måde grundlæggende med to registreringsenheder: Bopladser og løsfund, hver med sin egen indsamlingsstrategi. Varierer karakteren af lokaliteterne, vil indsamlingsmåden meget ofte variere tilsvarende. Selv om princippet kan være effektivt til at lokalisere bopladser, går systematikken i vid udstrækning tabt, og det er ikke muligt at sammenligne materiale fra bopladser med materiale uden for, dvs. såkaldt off-site materiale. ${ }^{10}$ 


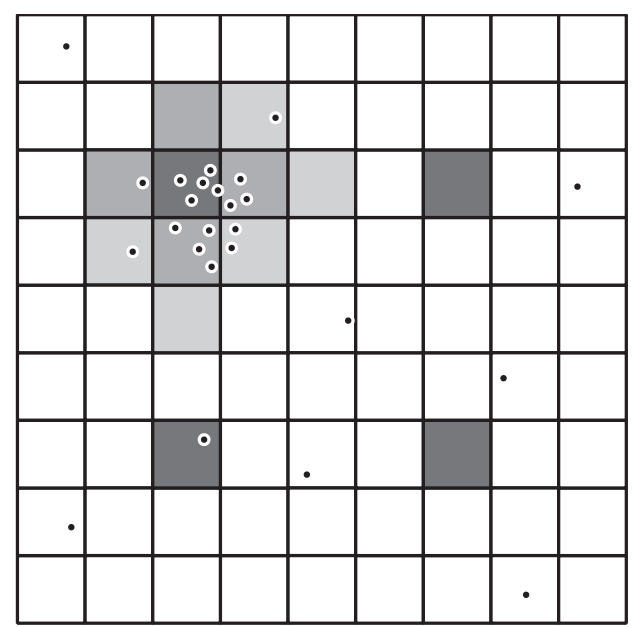

Udgangsfelt (initial unit)

1. udvidelse (1st addition)

2. udvidelse (2nd addition)
Fig. 2. Princippet i adaptive cluster sampling. Udgangspunktet er i dette tilfælde fire systematisk udlagte felter og en kritisk værdi på tre. Overstiges den kritiske værdi, så udvides samplingen med de felter, hvis sider ligger op til det aktuelle felt.

The principles of adaptive cluster sampling. The starting point in this example is four initial units. The critical value is set at three. If the critical value is exceeded, the adjacent units are sampled.

En fuldt systematisk indsamling inden for et fastlagt net opfylder heller ikke ønskerne til rekognosceringsmetoden. På den ene side kan man her vælge at dække hele området med en ensartet høj detaljeringsgrad ud fra et ideal om at registrere alt materiale. Det er sjældent praktisk muligt, og fremgangsmåden vil være uforholdsmæssig arbejdskrævende i forhold til udbyttet. Alternativt kan der udlægges nogle baner eller felter i undersøgelsesområdet efter faste eller randomiserede principper, hvorefter der inden for disse indsamles systematisk. ${ }^{11}$ Den variant af metoden tager imidlertid ikke hensyn til, at der rent faktisk er koncentrationer (clusters) i fundmaterialet, som vi er interesserede i at få afgrænset og karakteriseret så detaljeret som muligt.

De her skitserede fremgangsmåder kan betragtes som produkt af to yderpunkter i opfattelsen af det arkæologiske materiales rumlige karakter. Den konventionelle rekognoscering vægter lokaliteter, mens den systematiske indsamling er rettet mod en jæevn spredning. Reelt beskrives det arkæologiske materiale bedst som koncentrationer på en baggrund af jævn spredning, og i kortlægningen af landudnyttelsesstrategier over tid er det af interesse at få karakteriseret begge dele. Til netop den type problemstillinger er en ny samplingsmetode i de seneste 10 år blevet udviklet under betegnelsen adaptive cluster sampling. ${ }^{12}$ Metoden har først og fremmest været rettet mod problemstillinger i biologien, men det er for nylig blevet frem- 
hævet, at den passer ideelt til det arkæologiske materiale og derfor vil være en oplagt strategi i forbindelse med rekognoscering..$^{13}$

Metoden bygger indledningsvis på en enten randomiseret eller systematisk udlægning af spredte samplefelter over et større areal (fig. 2). Hvis en opsamling $i$ et af disse udgangsfelter overstiger en vis, fastsat mængde (den kritiske værdi), rekognosceres også nabofelterne. Hvis et eller flere af nabofelterne rummer mere end den fastsatte mængde udvides tilsvarende med nye felter omkring disse.

Felternes størrelse, tætheden af udgangsfelterne, den kritiske værdi for udvidelse, måden man udvider på, og hvordan felterne undersøges, er alle størrelser, man selv fastsætter indledningsvis efter konkrete problemstillinger og forhåndenværende ressourcer. Når indsamlingen først er igangsat, skal den imidlertid foregå konsekvent.

I et materiale med spredte koncentrationer vil metoden generelt være den mest effektive til at fremskaffe et repræsentativt udvalg. I forhold til en rent randomiseret udlægning af felter vil man med det samme antal felter tilmed opnå et større materiale, uden de statistiske egenskaber mistes. ${ }^{14}$ Samtidig har metoden den positive effekt, at fundkoncentrationer afgrænses. Adaptive cluster sampling opfylder dermed alle de opstillede krav til projektets rekognosceringsstrategi.

\section{Indsamling}

Som udgangspunkt for rekognosceringerne er der udlagt et net af samplefelter over det ca. $5 \mathrm{~km}^{2}$ store undersøgelsesområde (fig. 3). Engområder, veje og bebyggede arealer er ikke tilgængelige, og det reelle undersøgelsesområde er derfor noget mindre. Felterne måler 20x20 m og ligger regelmæssigt med en indbyrdes afstand på $40 \mathrm{~m}$. Det svarer til en arealmæssig dækning på ca. $11 \%$.

Felterne afsættes med landmålerstokke ved hjælp af en højpræcisionsGPS, og de afvandres af arkæologer og arkæologistuderende med indsamlingserfaring. Bearbejdet og ildskørnet flint, brændte sten, keramik, slagger og bearbejdet bjergart indsamles ligesom alt andet kulturmateriale, der formodes at være ældre end 200 år.

Den kritiske værdi, som fører til feltudvidelse, har reelt været en kompleks størrelse at håndtere. Inden for undersøgelsesområdet ligger spor efter aktiviteter fra hele oldtiden, middelalder og nyere tid. De forskellige perioder kommer til udtryk på vidt forskellig måde, hvilket den kritiske værdi må tage højde for. Resultatet er, at der opereres med ikke en, men flere kritiske værdier: En for genstandstyper, en for mængde af flint, en for mængde af keramik og en for mængde af brændte sten. Hvis bare en af de kritiske værdier overskrides, så udvides der. De konkrete vær- 


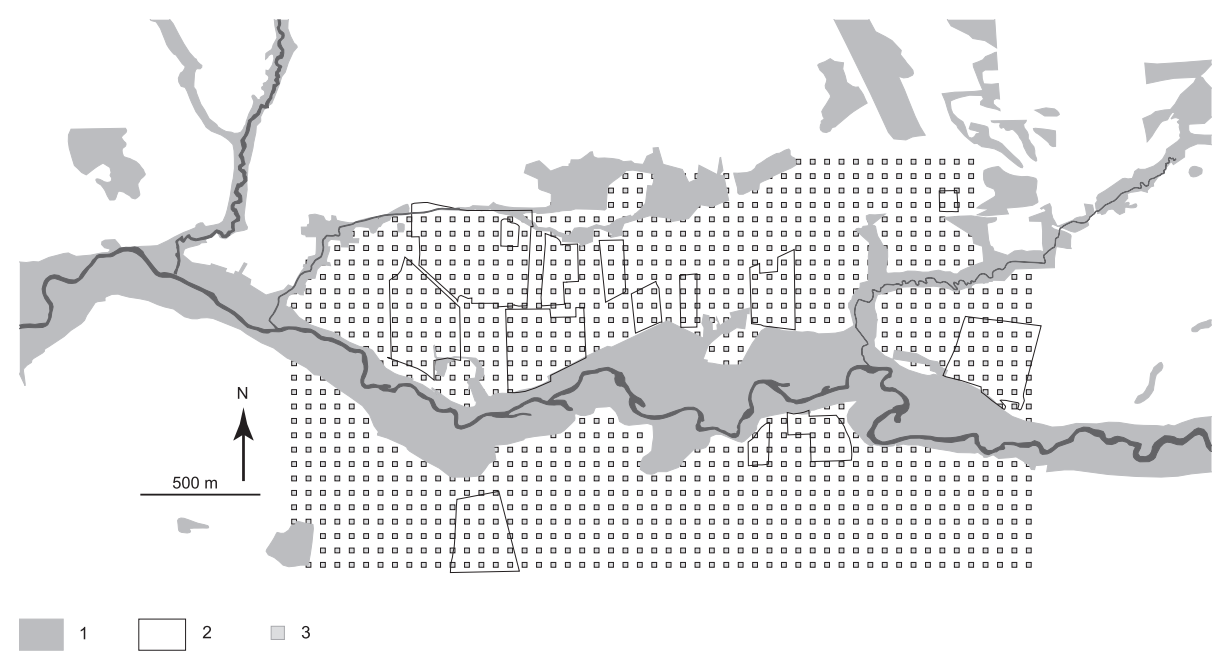

Fig. 3. Undersøgelsesområdet med det udlagte net af samplefelter. 1: Vådbund; 2: Rekognoscerede marker; 3: Udgangsfelter.

The investigation area with the grid of initial sample units. 1: Wetland; 2: Surveyed fields; 3: Initial sample units.

dier blev fastsat efter en indledende rekognosceringsrunde, hvor kun udgangsfelter blev undersøgt. De gav et indtryk af materialets fordeling og dermed grundlag for at afgøre, hvilke værdier der skal føre til feltudvidelse.

Principielt forudsætter en feltudvidelse, at det indsamlede materiale er klassificeret og optalt, hvilket vanskeligt lader sig gøre i felten. Af praktiske årsager, som markernes tilgængelighed og effektiv udnyttelse af tiden, er det imidlertid en klar fordel faktisk at udvide løbende baseret på et skøn. Hvis man opererer med et lidt højt sat skøn, vil der snarere komme for mange end for få feltudvidelser, og de overskydende felter kan altid sorteres fra i de efterfølgende beregninger. Skulle der ved efterbearbejdningen vise sig at mangle felter, må man vende tilbage og undersøge disse ved en senere lejlighed.

I praksis har adaptive cluster sampling fungeret som en udmærket metode til systematisk afgrænsning af fundkoncentrationer og til at få et generelt overblik over området. Metoden kan eksemplificeres ved en konkret rekognosceringssituation på en mark i den sydvestlige del af undersøgelsesområdet, hvor en lille boplads fra tidligneotikum/tidlig mellemneolitikum afgrænses (fig. 4).

På marken er 18 udgangsfelter tilgængelige ved den indledende afsøgning. Kun i et felt overskrides den kritiske værdi, der på forhånd er fastsat 

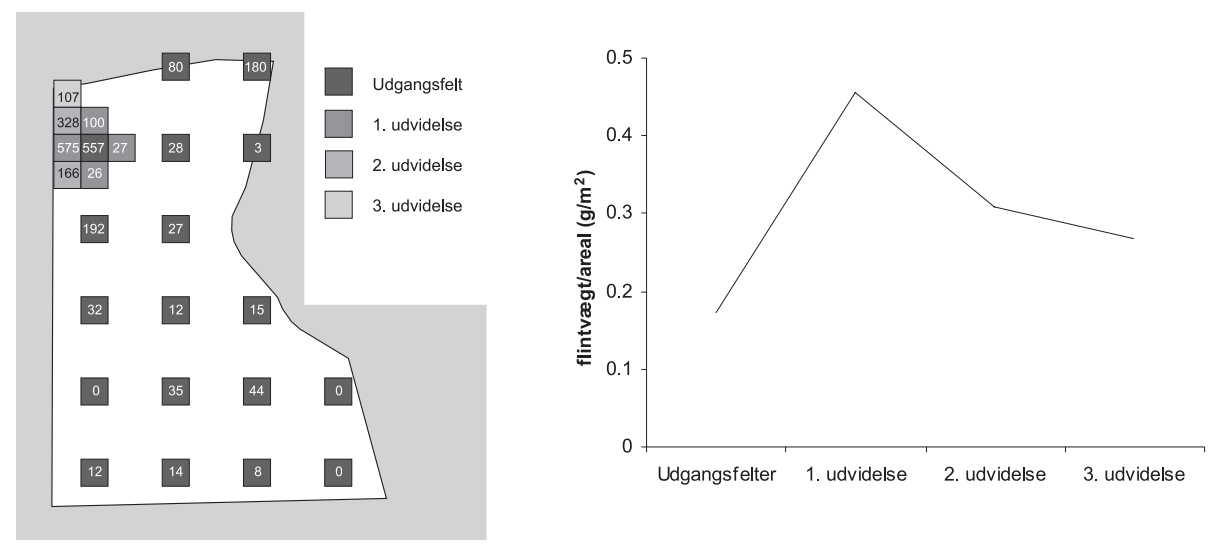

Fig. 4. Adaptive cluster sampling i praksis. Metoden er her eksemplificeret ved rekognoscering på en mark i den sydvestlige del af undersøgelsesområdet. I de enkelte felter er vægten af bearbejdet flint angivet. Den kritiske værdi er fastsat til $200 \mathrm{~g}$ bearbejdet flint. Grafen angiver forholdet mellem vægt af bearbejdet flint og undersøgt areal i de forskellige faser af rekognosceringen.

Adaptive cluster sampling exemplified by the survey of a field in the south-western part of the investigation area. The squares are labelled with the weight of worked flint. The critical value is $200 \mathrm{~g}$. The graph depicts the relationship between the weight of worked flint and the size of the surveyed area at different stages of the survey.

til $200 \mathrm{~g}$ bearbejdet flint. Det udløser en udvidelse med fire felter. Af de fire udvidelsesfelter har kun feltet mod vest en flintvægt, der overskrider den kritiske værdi. Flintkoncentrationen er da at betragte som afgrænset på tre sider, mens endnu en udvidelse må foretages omkring det vestlige udvidelsesfelt. Der burde i denne situation udvides med tre felter, men kun to er tilgængelige, idet det tredje falder på en mark, der ikke kan rekognosceres. Af de to tilgængelige felter overskrider flintmængden i det nordligste $200 \mathrm{~g}$, hvorfor der her må udvides med to felter. Igen er kun et felt $\mathrm{i}$ praksis tilgængeligt, men dette har en flintmængde betydeligt under den kritiske værdi. Flintkoncentrationen er dermed afgrænset mod nord, syd og øst, mens udvidelserne mod vest må vente til arealet her bliver pløjet. Afgrænsningen kan følges ved for hvert trin i proceduren at beregne forholdet mellem vægten af indsamlet flint og størrelsen af det undersøgte areal. Her ses, at værdien er lav i udgangssituationen, men at den stiger kraftigt i den første fase med feltudvidelser. Ved anden feltudvidelsesfase falder værdien, hvilket antyder, at lokaliteten er ved at blive afgrænset. I forbindelse med den tredje udvidelse fortsætter den faldende tendens, men den når ikke niveauet for udgangsfelterne. 
I perioden 2000-2002 er 210 udgangsfelter blevet undersøgt, og hertil kommer 73 udvidelsesfelter. Der er således inden for et areal på 75 ha blevet samplet 11,3 ha. ${ }^{15}$

\section{Registrering}

Registreringen af fundmaterialet foregår basalt set på to niveauer, dels på et opsamlingsniveau og dels på et genstandsniveau (fig. 5).

En opsamling er en indsamlingsbegivenhed i et konkret felt. Opsamlingen defineres altså både ved et tidspunkt og et sted. Det giver mulighed for at vende tilbage til et felt og indsamle supplerende materiale under nye observationsforhold, således at det nyopsamlede materiale holdes adskilt fra den primære opsamling, og problemer med sammenligning undgås.

Ved hver opsamling registreres en række generelle faktorer i felten af hensyn til sammenligneligheden opsamlingerne imellem. Da felterne til tider går på tværs af markskel eller lignende, er det ikke altid muligt at undersøge disse i deres helhed. Derfor registreres, hvor stor en procentdel af feltet, der kan undersøges. Indsamlingens varighed ligger fast på 20 minutter, men den reguleres naturligvis i forhold til undersøgelsesprocenten.

I efterbearbejdningsfasen karakteriseres opsamlingernes indhold. Vægt og antal af bearbejdet og ildskørnet flint giver et overblik over fundtætheden, mens forholdet mellem vægt og antal kan ses som et udtryk for, hvor intensivt råmaterialet udnyttes. Den bearbejdede flint karakteriseres med hensyn til produktion og teknik for at kunne udnytte det informationspotentiale, der ligger i selve flintproduktionen både med hensyn til kronologi og aktivitetsmønstre. ${ }^{16}$

Den totale mængde keramik fra de enkelte opsamlinger vejes og optælles på lige fod med flintmaterialet. Fragmenteringen vanskeliggør ofte en nærmere karakteristik af skårmaterialet, og derfor opgøres keramikken på opsamlingsniveau blot inden for fire godstyper defineret ud fra brænding, magring og struktur. Sammenholdt med det øvrige fundmateriale ser de udskilte godstyper dog ud til at give ret gode dateringsmæssige referencer.

Fra opsamlingerne udskilles karakteristiske genstande, der tildeles et unikt nummer og klassificeres selvstændigt. Af flint udtages sekundært modificerede stykker (redskaber), blokke og diagnostiske afspaltninger. Ligeledes udtages bjergartsredskaber og inden for keramikken en række karakteristiske skår. Genstandene typebestemmes i forhold til materialerelative klassifikationssystemer. For flintmaterialet anvendes f.eks. en formaliseret udgave af det almene danske klassifikationssystem. ${ }^{17}$ 


\begin{tabular}{|c|c|c|c|}
\hline & Beskrivelsesvariabler & Forklaring & Værdier/kategorier \\
\hline \multirow{3}{*}{ 으 } & Opsamlingsnr & Fortløbende nummerering af opsamlinger & \\
\hline & UTM-koordinater & $\begin{array}{l}\text { Lokalisering i rum ved koordinaterne på } \\
\text { feltets SV-hjørne }\end{array}$ & \\
\hline & Dato & Lokalisering i tid ved en dato & \\
\hline \multirow{6}{*}{ 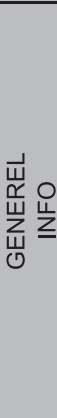 } & Dyrkningstilstand & Markens dyrkningstilstand & $\begin{array}{l}\text { Harvet } \\
\text { Pløjet } \\
\text { Spiret } \\
\text { Høstet }\end{array}$ \\
\hline & Overfladeforhold & Graden af markens nedregning & $\begin{array}{l}\text { Ikke afregnet } \\
\text { Afregnet } \\
\text { Nedregnet }\end{array}$ \\
\hline & Sigtbarhed & Sigtbarheden i feltet & $\%$ \\
\hline & Undersøgelsesprocent & Andelen af feltet, der kunne undersøges & $\%$ \\
\hline & Indsamlingsvarighed & $\begin{array}{l}\text { Antal minutter anvendt på indsamling i } \\
\text { feltet }\end{array}$ & \\
\hline & Deltagere & $\begin{array}{l}\text { Indsamler hentet fra liste over samtlige } \\
\text { deltagere i rekognosceringen }\end{array}$ & Navn \\
\hline \multirow{14}{*}{$\begin{array}{l}\text { 옹 } \\
\text { 온 } \\
\text { ڤ }\end{array}$} & Samlet vægt & Totalvægt af bearbejdet flint & $\mathrm{g}$ \\
\hline & Samlet antal & Optælling af bearbejdet flint & \\
\hline & Vægt ildskørnet flint & Vægten af ildskørnet flint & $\mathrm{g}$ \\
\hline & Antal ildskørnet flint & Optælling af ildskørnet flint & \\
\hline & Produktion & $\begin{array}{l}\text { Optælling af bearbejdet flint inden for } \\
\text { produktionskategorier }\end{array}$ & $\begin{array}{l}\text { Afslag } \\
\text { Flække - A/B/Udef. } \\
\text { Mikroflække - A/B/Udef. } \\
\text { Bearbejdet frostskive } \\
\text { Kerne } \\
\text { Kerneredskab }\end{array}$ \\
\hline & Teknik & $\begin{array}{l}\text { Optælling af afspaltningsmateriale inden } \\
\text { for teknologiske kategorier }\end{array}$ & $\begin{array}{l}\text { Blød } \\
\text { Hård } \\
\text { Udefineret }\end{array}$ \\
\hline & Samlet vægt & Totalvægt af keramik & $\mathrm{g}$ \\
\hline & Samlet antal & Optælling af keramik & \\
\hline & Gods & $\begin{array}{l}\text { Optælling af keramik inden for forskellige } \\
\text { godstyper }\end{array}$ & $\begin{array}{l}\text { gennembrændt, fint magret } \\
\text { hårdt brændt, fint magret, lagdelt } \\
\text { let brændt, fint magret, lagdelt } \\
\text { let brændt, groft magret, smuldrende }\end{array}$ \\
\hline & Brændte sten & Vægt af ildskørnede sten & $\mathrm{g}$ \\
\hline & Slagger & Vægt af slagger & g \\
\hline & Bjergart & Optælling af bearbejdet bjergart & \\
\hline & Glas & Optælling af glasskår & \\
\hline & Andet & Optælling af andet indsamlet materiale & \\
\hline \multirow{3}{*}{ 으 } & Beskrivelsesvariabler & Forklaring & Værdier \\
\hline & X-nr & $\begin{array}{l}\text { Fortløbende nummerering af udskilte } \\
\text { genstande }\end{array}$ & \\
\hline & Opsamlingsnr & $\begin{array}{l}\text { Henvisning til den opsamling, hvorfra } \\
\text { genstanden stammer }\end{array}$ & \\
\hline $\begin{array}{l}\text { 웅 } \\
\text { 온 } \\
\text { ㅁ }\end{array}$ & Genstandstype & $\begin{array}{l}\text { Klassfikation af genstanden. Flere } \\
\text { alternative klassifikationssystemer for } \\
\text { forskellige materialekategorier }\end{array}$ & $\begin{array}{l}\text { Flint - skraber - afslag } \\
\text { Flint - fladehugget pil } \\
\text { Flint - bor - kerne } \\
\text { Bjergart - hvæssesten } \\
\text { osv. }\end{array}$ \\
\hline
\end{tabular}

Fig. 5. Skematisk fremstilling af beskrivelsessystemet for opsamlingerne og de enkelte genstande. I praksis er dette indeholdt i en digital database.

Schematic representation of the registration system. The registration system is contained in digital database. 


\section{Resultater}

Efter at have gennemført rekognosceringerne i 2000-2002 er der, med forbehold for den endnu relativt begrænsede dækning af undersøgelsesområdet, opnået en række resultater, der kan give et billede af metodens udsagnsværdi.

Keramikken fordeler sig efter et tydeligt mønster med hensyn til de forskellige godstyper (fig. 6). Den gennembrændte, fintmagrede keramik, der dateres til middelalder og nyere tid, udviser en jæevn spredning. Dette billede må generelt opfattes som udtryk for gødskning, hvor møddingsmateriale indeholdende blandt andet keramik er blevet spredt over de dyrkede arealer.

Den hårdtbrændte, fintmagrede og lagdelte keramik må primært dateres til jernalder, i enkelte tilfælde måske til yngre bronzealder. I den østlige del af undersøgelsesområdet ses en markant koncentration af denne godstype.

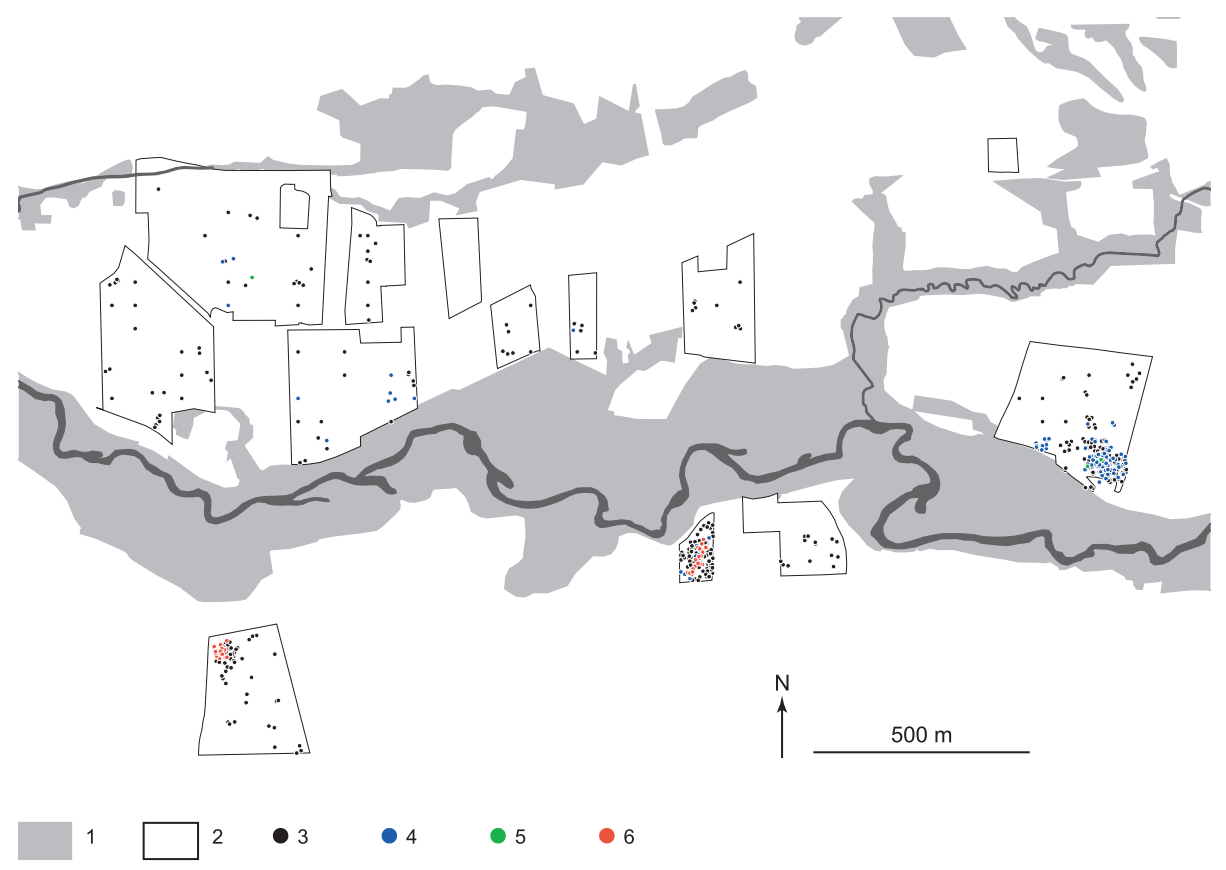

Fig. 6. Udbredelseskort for keramikken med markering af de forskellige godstyper. 1: Vådbund; 2: Rekognoscerede marker; 3: Gennembrændt, fint magret keramik; 4: hårdt brændt, fint magret, lagdelt keramik 5: Let brændt, fint magret, lagdelt keramik; 6: Let brændt, groft magret, smuldrende keramik.

The distribution of different fabrics of ceramics. 1: Wetland; 2: Surveyed fields; 3: Fully fired, finely tempered ceramics; 4: Well-fired, finly tempered, layered ceramics; 5 : Moderately fired, finely tempered, layered ceramics; 6: Moderately burnt, coarsly tempered, friable ceramics. 
Fig. 7. Typisk eksempel på en afslagsblok fra undersøgelsesområdet. For at opnå størst mulige afslag er smalsiderne anvendt som platforme, mens afspaltningsfladen udgøres af stykkets bredside. 2:3. - Tegning: Louise Hilmar.

A typical example of a flake core from the investigation area. The narrow sides are used as platforms to produce flakes from the flat face of the core. 2:3.

Fig. 8. Afslag fra produktion af firesidede flintøkser. I undersøgelsesområdet er der kun fundet $\varnothing$ kseafslag fra den afsluttende tilhugning med mellemstykke og trykstok. 2:3. - Tegning: Louise Hilmar.

Flakes from four-sided axe production. Only the last stages of reduction with antler punch and pressure flaker are represented in the flint debitage of the investigation area. 2:3.
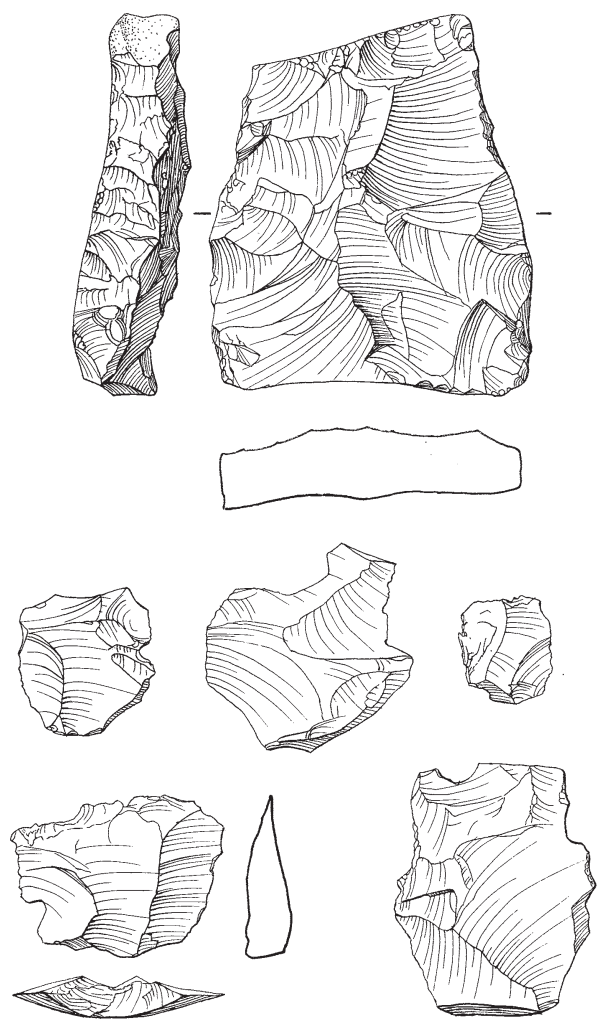

Koncentrationen, der er sammenfaldende med fund af knusesten, jernslagger og oppløjede kogesten, opfattes som en boplads fra jernalderen. Den letbrændte, fintmagrede og lagdelte keramik er meget dårligt repræsenteret i undersøgelsesområdet. Det er den mindst kronologisk signifikante godstype, men den synes i dette tilfælde at følge jernalderkeramikkens spredningsbillede.

Den letbrændte, groftmagrede og smuldrende keramik kendetegner særligt stenalder og ældre bronzealder. Udbredelse af denne godstype aftegner på sydsiden af Kongeåen to tydelige koncentrationer, der må tolkes som bopladser og ud fra det samlede genstandsmateriale dateres til tidlig neolitikum/tidlig mellemneolitikum. Inden for undersøgelsesområdet er denne keramiktype kun fundet på disse to lokaliteter.

I kraft af undersøgelsesområdets placering i det flintfattige område sydvest for hovedstilstandslinien har den bearbejdede flint en række særpræg. Med ca. 14 stk. flint pr. felt og en gennemsnitsvæegt på blot $10 \mathrm{~g}$ pr. bearbejdet stykke flint (inklusiv blokke) er den absolutte flintmængde meget lav. At der i området kun går ca. 10 afspaltninger pr. blok er derfor ikke et udtryk for en ekstensiv udnyttelse af flinten, men i stedet vidnesbyrd om, at blokkene fra starten er meget små. Faktisk synes bestræbelserne på at få 
størst mulige afspaltninger ud af de små flintknolde at have ledt til en særegen blokteknik (fig. 7). I næste led af reduktionen ses knapheden på flint i form af en ekstrem høj frekvens af redskaber i forhold til afspaltninger, ligesom en stor andel af redskaberne er ukurante, retoucherede stykker. Tendensen understreges af det faktum, at ca. $40 \%$ af skraberne fundet $\mathrm{i}$ undersøgelsesområdet er lavet på frostskiver.

På baggrund af den begrænsede flintforekomst er fundene af større fladehuggede stykker og firesidede økser interessante. Der er tale om redskabstyper, som i udgangspunktet kræver store flintemner af høj kvalitet. Disse fund adskiller sig da også materialemæssigt markant fra den lokale flint, hvilket antyder forbindelser udadtil. Karakteren af den udefrakommende flint kan præciseres yderligere, idet diagnostiske afslag fra produktion af firesidede økser og fladehuggede stykker er blevet udskilt. ${ }^{18} \mathrm{Her}$ er

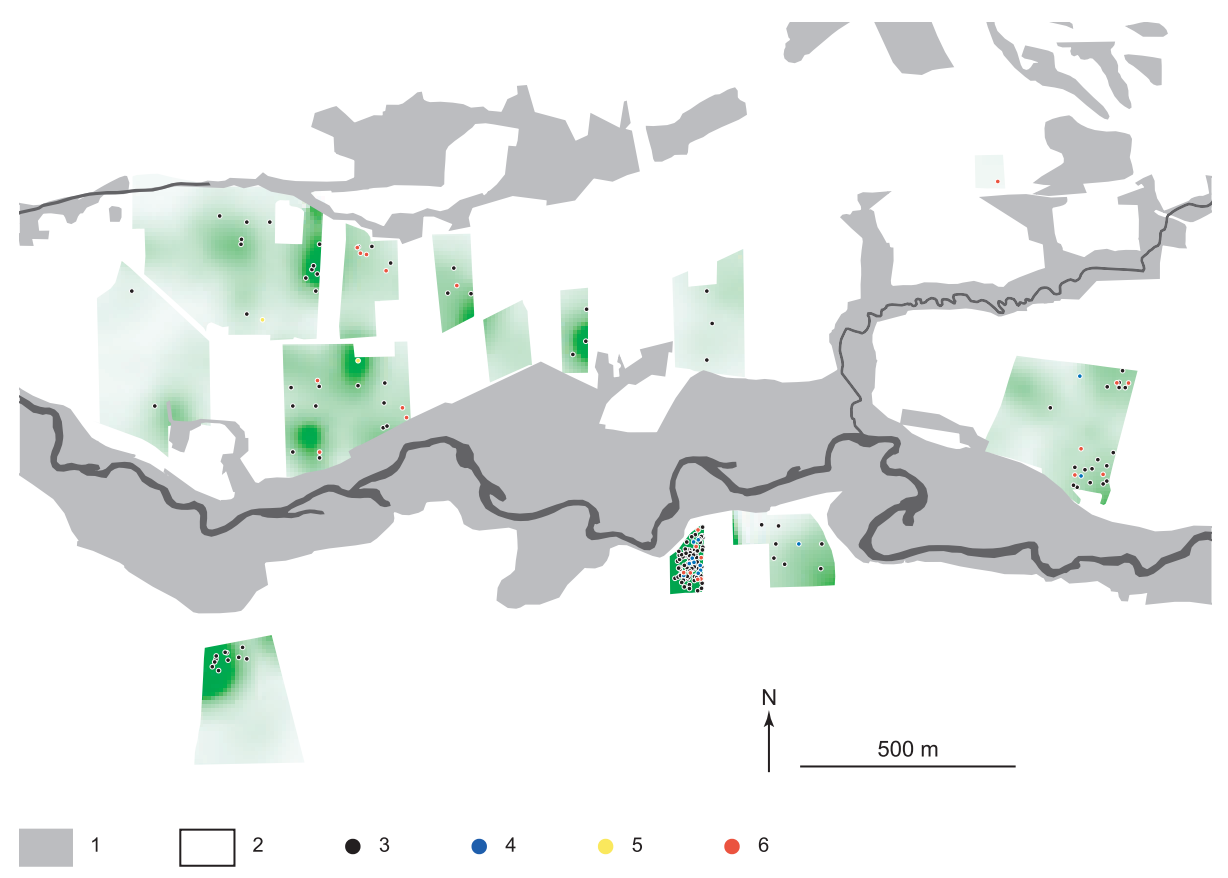

Fig. 9. Udbredelseskort for ledetyper af flint fra forskellige perioder. Den grønne tone i baggrunden angiver flintkoncentrationen interpoleret efter vægten af bearbejdet flint i de undersøgte felter. 1: Vådbund; 2: Rekognoscerede marker; 3: Udateret; 4: Tragtbægerkultur; 5: Enkeltgravskultur; 6: Senneolitikum/ældre bronzealder.

The distribution of diagnostic flint tools from different periods. The intensity of the green colour gives a relative measure of the density of worked flint. 1: Wetland; 2: Surveyed fields; 3: Undated; 4: The Funnel Beaker Culture; 5: The Single Grave Culture; 6: the late Neolithic/ early Bronze Age. 
det for det første påfaldende, hvor lidt der er, og for det andet tydeligt, at kun den afsluttende reduktion er repræsenteret i materialet (fig. 8). Man må derfor forestille sig, at de større flintemner er kommet til området enten som færdige redskaber eller som forarbejder på et meget sent stadie. På samme måde er det tydeligt, at langt de fleste af disse redskaber sekundært er blevet omhugget for at udnytte flinten til det yderste.

Spredningen af bearbejdet flint inden for undersøgelsesområdet afspejler delvist de udbredelsesmønstre, der kendetegner keramikken (fig. 9). Grundlæggende er der to markante koncentrationer syd for Kongeåen svarende til de tidligneolitiske/tidlig mellemneolitiske bopladser. Nord for Kongeåen er de rekognoscerede områder længst mod vest karakteriseret ved en meget lav flintmængde, hvilket også gør sig gældende for arealerne længere mod øst. I den centrale del af undersøgelsesområdet nord for Kongeåen ses dog et større område med en let forhøjet flintkoncentration. Diffuse flintkoncentrationer forekommer også længst mod øst på marken med jernalderbopladsen. Udbredelsen af udaterede, formelle flintredskaber, der primært må afspejle aktiviteter inden for yngre stenalder, følger overordnet set mønstrene i flintkoncentrationen.

Endelig er der de daterbare flintredskaber. De viser, at tragtbægerkultur primært findes på den østlige af de allerede omtalte bopladser syd for Kongeåen. Hertil kommer spredte fund i den østligste del af undersøgelsesområdet. Den sydvestlige boplads, der ovenfor blev anvendt som eksempel på rekognosceringsmetoden, er sikkert dateret til tragtbægerkultur ud fra keramikken, men den har - formodentlig på grund af sin ringe størrelse - ingen diagnostiske flintredskaber.

Kun to flintredskaber kan sikkert henføres til enkeltgravskultur. Det drejer sig om en tyknakket flintøkse og en omhugget mejsel fundet centralt i den nordlige del af undersøgelsesområdet med en forholdsvis lille indbyrdes afstand. Placeringen er sammenfaldende med den før omtalte let forhøjede flintkoncentration.

Fladehuggede redskaber, karakteristiske for senneolitikum og ældre bronzealder, forekommer overvejende inden for tre områder. Der er gjort fund på den markante, østlige tragtbægerlokalitet syd for Kongeåen. På marken med jernalderbopladsen mod øst, og i det centrale område nord for Kongeåen, der begge er karakteriseret ved let forhøjet flintkoncentration, er der ligeledes fundet spredte genstande fra perioden (fig. 10).

Med de forbehold, der må tages for det ret begrænsede materiale, tegner der sig således nogle overordnede mønstre i flint- og keramikspredningen. Fundmaterialet fra både tragtbægerkultur og jernalder er samlet i tætte koncentrationer på regulære bopladser. Fra enkeltgravskultur til ældre bronzealder er der tale om mere diffuse fundspredninger over større områder, hvilket antyder en noget anderledes bosættelses- og/eller landudnyttelsesstrategi. 


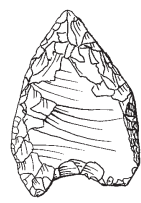

1

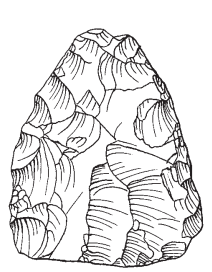

4

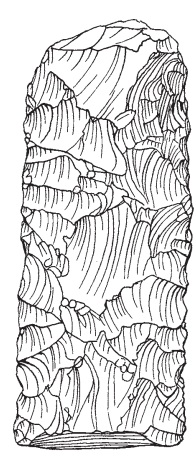

6

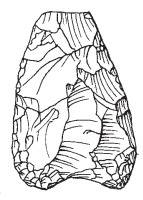

2

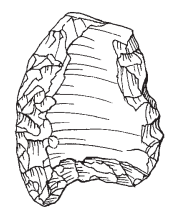

3

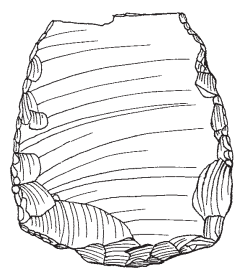

5

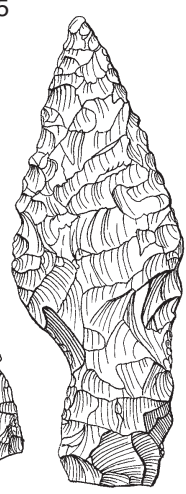

9

Fig. 10. Udvalgte flintredskaber fra senneolitikum/ældre bronzealder. 1-5: fladehuggede pilespidser og forarbejder til pilespidser, 6: flintdolk af type VIb, 7: fladehugget segl med tandet æg, 8: fladehugget asymmetrisk segl med fortykket ende, 9: omhugget dolk/segl. 2:3. - Tegning: Louise Hilmar.

Selected flint tools from Late Neolithic and Early Bronze Age. 1-5: Bifacial arrowheads, 6: Flint dagger of type VIb, 7: Bifacial serrated sickle, 8: Bifacial asymmetrical sickle, 9: Reworked bifacial dagger/sickle. 2:3.

Bortset fra spredte fund fra ældre stenalder dateres de første aktivitetsspor inden for højgruppens område på nordsiden af Kongeåen til enkeltgravskultur. Aktivitetssporene fortsætter her og tiltager i antal i senneolitikum og ældre bronzealder. De ældste høje i gruppen er sandsynligvis anlagt i enkeltgravskultur, mens hovedparten er fra senneolitikum og især ældre bronzealder. ${ }^{19}$ Der er således et sammenfald mellem dateringerne af højgruppen og aktivitetssporene på nordsiden af Kongeåen.

Betragtes fundspredningen lidt mere detaljeret er det imidlertid interessant, at genstandene fra senneolitikum og ældre bronzealder er koncentreret dels i en næsten højtom zone imellem de to koncentrationer af høje inden for højgruppen, og dels øst og syd for gruppen, mens der blandt selve højene er fundtomt. Det vil sige, at det senneolitiske-ældre bronzealderlige fundmateriale tilsyneladende er komplementært til højgruppen. I den forbindelse kan det dog ikke udelukkes, at selve højbyggeriet i et eller andet omfang har påvirket billedet, idet den omfattende opmagasinering af overfladetørv i højene kan have reduceret fundkoncentrationen i nærheden af disse. Blandt andet blev der ved Thranes undersøgelse af Storehøj i 1961 konstateret en del bopladsmateriale i højfylden. ${ }^{20}$ 


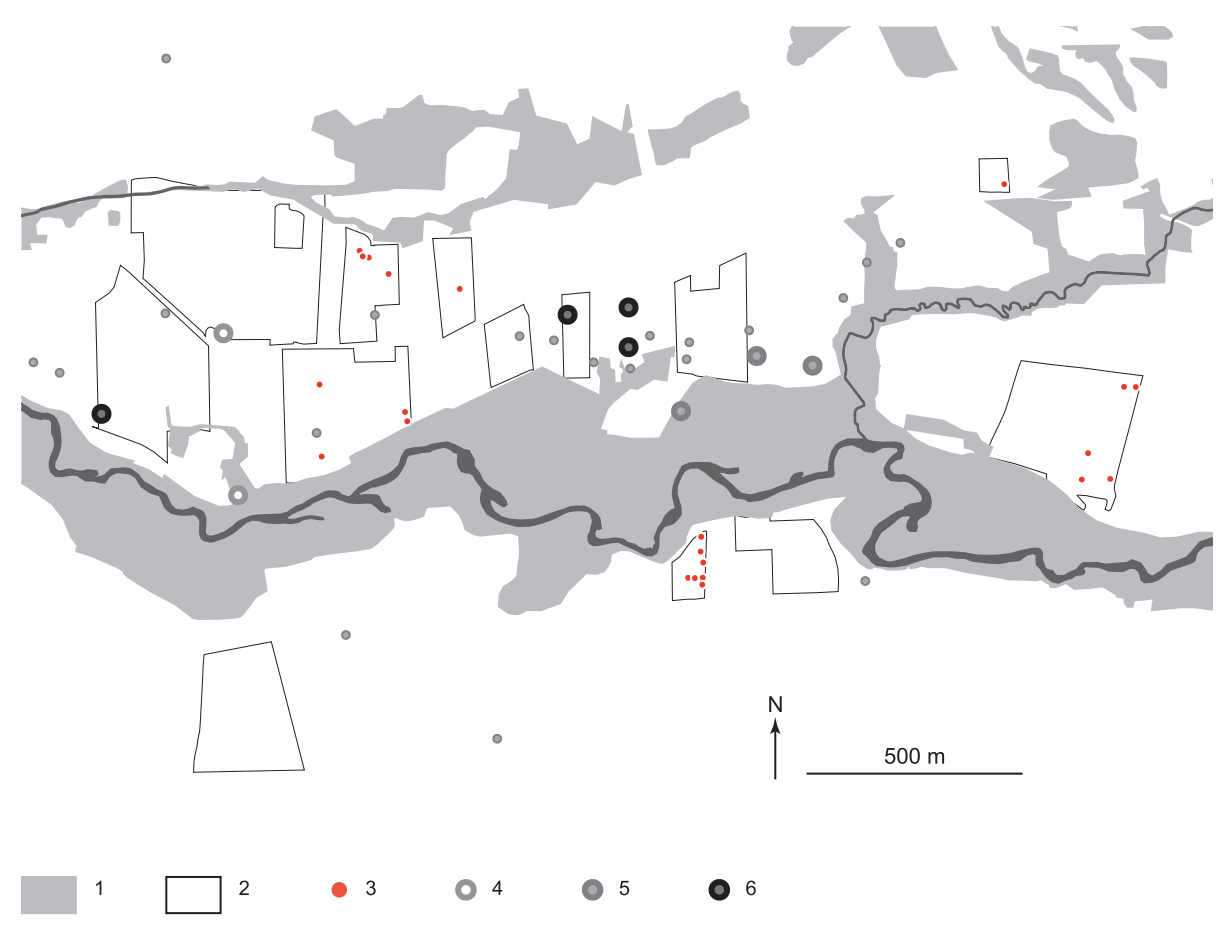

Fig. 11. Udbredelsen af flintredskaber fra senneolitikum/ældre bronzealder sammenholdt med højfyldens udvaskningsgrad. Udvaskningen er blevet bestemt i ni høje. 1: Vådbund; 2: Rekognoscerede marker; 3: Flintredskaber fra senneolitikum/ældre bronzealder; 4: Høje med stærkt udvasket fyld; 5: Høje med let udvasket fyld; 6: Høje med ikke-udvasket fyld.

The distribution of late Neolithic and Early Bronze Age flint tools compared to the extent of soil leaching in the sods of the barrows. Leaching has been determined in nine barrows. 1: Wetland; 2: Surveyed fields; 3: Flint tools from the late Neolithic/early Bronze Age; 4: Barrows with strongly leached sods; 5 : Barrows with moderately leached sods; 6 . Barrows with no leaching.

Udbredelsesbilledet kan holdes op imod oplysninger fra boringerne i gravhøjene (fig. 11). I flere af højene er tørven kraftigt udvasket, i nogle tilfælde med en markant podsolering, der indikerer en forholdsvis langvarig ekstensiv udnyttelse af området omkring højen forud for byggeriet. Andre høje har kraftige muldlag, der enten kan være opbygget i skov eller gennem længere tids intensiv dyrkning og jordbehandling. Både jordbundsforholdene og rekognosceringsresultaterne afspejler langvarige strukturer, og sammenholdt kan de danne udgangspunkt for en hypotetisk zonering af landskabet. Øst for den diffuse senneolitiske-ældre bronzealderlige fundspredning er der først en gruppe høje med ikke-udvasket materiale og derefter en delvist udvasket zone, hvilket kan antyde en gradvis overgang 
fra et intensivt til et ekstensivt udnyttet område. Mod vest er de to nærmeste høje kraftigt udvaskede, mens en tredje mere fjerntliggende høj ikke er udvasket. Det kunne eventuelt afspejle et ekstensivt areal, der længere mod vest går over i skov. Rekognosceringerne kan på denne måde danne fortolkningsgrundlag for miljøanalyserne af gravhøjenes tørv, men det skal samtidig understreges, at der er en række kildekritiske problemer. Der mangler stadig dateringer af flere af højene, rekognosceringsmaterialet og antallet af jordbundsundersøgelser er endnu begrænset, og der er behov for en bestemmelse af vegetationen på tørvene i de forskellige høje.

\section{Konklusion}

Rekognosceringerne ved Tobøl-Plougstrup kan ses som et eksempel på adaptive cluster sampling anvendt i praksis. Metoden har vist sig at være effektiv og håndterbar, og den vil være oplagt ikke blot til rekognoscering, men også til sampling og afgrænsning af koncentrationer i en række andre arkæologiske data, der kan beskrives som koncentrationer på baggrund af en jævn spredning.

Metoden udgør dybest set en formalisering og systematisering af praksis ved rekognosceringer. Detaljeringsgraden øges, hvor der er informationer at hente, men samtidig bevares systematikken. Dermed er der en sikkerhed for, at de afdækkede strukturer afspejler reelle mønstre i fundmaterialet og ikke blot er kunstige produkter af en bestemt rekognosceringsprocedure.

Nødvendigheden af den systematik, som metoden rummer, kommer særligt tydeligt til udtryk i forbindelse med fundmaterialet fra enkeltgravskultur til ældre bronzealder. De lokaliteter, der forud for rekognosceringerne var registreret fra disse perioder, er primært påtruffet i forbindelse med tragtbægermateriale. Der er tilsyneladende en tendens til, at udbredelsesbilledet fra enkeltgravskultur til ældre bronzealder i høj grad afspejlede en mere intensiv rekognosceringsindsats på de kendte, let identificerbare og fundrige tragtbægerpladser. De mere diffuse fundspredninger fra enkeltgravskultur til ældre bronzealder blev derfor næsten kun opfanget her. Det udbredelsesbillede, der tegner sig efter rekognosceringerne med adaptive cluster sampling, rummer såvel fundene inden for tragtbægerpladserne som fordelingen i landskabet generelt. Dermed er der etableret et væsentligt bedre udgangspunkt for en diskussion af de problemstillinger, som det overordnede projekt omkring højgruppen ved Tobøl-Plougstrup forsøger at belyse.

I første omgang er det naturligvis især på det lokale niveau, at rekognosceringerne bidrager med oplysninger. Resultaterne kan holdes op imod de øjebliksbilleder i tid og rum af det forhistoriske landskab, som de naturvidenskabelige analyser af jordprøverne fra gravhøjene giver. På den måde 
kan de to kildegrupper sammen belyse, hvorledes højgruppen dynamisk udvikler sig i relation til bosættelse og landskab.

Det er imidlertid også klart, at der i rekognosceringsmaterialet faktisk er informationer at hente om mere overordnede geografiske strukturer. Flintmaterialet giver f.eks. et indtryk af områdets rolle i distributionen af flint i neolitikum. Der er tilsyneladende allerede i tragtbægerkultur etableret udvekslingsforbindelser, og disse er ganske givet af betydning for forståelsen af den placering, som området senere får i det bronzealderlige kommunikations- og distributionsnetværk.

Rekognosceringerne dækker endnu kun et begrænset udsnit af undersøgelsesområdet, men det er målet at fortsætte indsatsen for at opnå et tilsvarende indblik i aktivitetssporene på de resterende arealer. I form af højenes vidnesbyrd om landskabsudnyttelsen er der i Tobøl-Plougstrup en unik kontekst, som disse resultater kan indgå i.

\section{NOTER}

1. Aner \& Kersten 1986.

2. Boye 1896, Thrane 1963a og Thrane 1963b.

3. Breuning-Madsen \& Holst i tryk.

4. Holst m.fl. 2001.

5. Jensen 1998 og Rasmussen 1998.

6. Holst m.fl. 2001.

7. Undersøgelsen af Skelhøj, sb. 95, Føvling sogn, Malt herred, Ribe amt gennemføres som et samarbejde mellem Nationalmuseet; Forhistorisk Arkæologi, Aarhus Universitet; Geografisk Institut, Københavns Universitet; Lejre Historisk-Arkæologisk Forsøgscenter og Museet på Sønderskov. Udgravningen er finansieret af Statens Humanistiske Forskningsråd.

8. Rekognosceringsprojektet ved Tobøl-Plougstrup er gennemført med hjælp fra en række personer og institutioner. Der skal rettes en stor tak til Ribe amts Museumsråd for økonomisk støtte og Egnsmuseet på Sønderskov for logi til projektdeltagerne. Desuden takkes Thomas Andersen, Søren Timm Christensen, Andreas Siegfried Dobat, Mads Dengsø Jessen og Niels Nørkjær Johannsen for medvirken i rekognosceringerne. Professor Henrik Breuning-Madsen, Geografisk Institut, Københavns Universitet, takkes for samarbejdet omkring jordbundsundersøgelserne i området.

9. Andersen 1998.

10. Bintliff \& Snodgrass 1988.

11. Binford 1964.

12. Thompson 1990 og Thompson \& Seber 1996.

13. Orton 2000 , s. 38.

14. Orton 2000, s. 98, 135 og Thompson 1990, s. $1055 f f$.

15. Afvandringen af de 210 udgangsfelter og de 73 udvidelsesfelter svarer til en effektiv afsøgningstid på 94 timer. Det reelle tidsforbrug pr. felt til afsætning, rekognoscering og nedpakning ligger imidlertid på omkring 45 minutter.

16. Eriksen 2000.

17. Petersen 1993. 
18. Stafford 1998 og Vemming-Hansen \& Madsen 1983.

19. Aner \& Kersten 1986.

20. Thrane 1963a.

\section{LITTERATUR}

Andersen, B. 1988: Udgravning af forskellige anlægstyper: Rekognoscering. Arkceologisk Felthåndbog. 1. udgave. Det arkæologiske Nævn. København.

Aner, E. \& K. Kersten 1986: Die Funde der älteren Bronzezeit des nordischen Kreises in Dänemark, Schleswig-Holstein und Niedersachsen. Bd. VIII. Neumünster.

Binford, L.R. 1964: A consideration of archaeological research design. American Antiquity, vol. 29, nr. 4, s. 425-41.

Bintliff, J. \& A. Snodgrass 1988: Off-site Pottery Distributions: A Regional and Interregional Perspective. Current Antropology, vol. 29, nr. 3, s. 506-513.

Boye, V. 1896: Fund af Egekister fra Bronzealderen i Danmark. København.

Breuning-Madsen, H. \& M.K. Holst i tryk: Soil description system for burial mounds - development and application.

Eriksen, B.V. 2000: Indledning. I: B.V. Eriksen (red.): Flintstudier. En håndbog i systematiske analyser af flintinventarer, s. 9-17. Århus.

Holst, M.K., H. Breuning-Madsen \& M. Rasmussen 2001: The South Scandinavian barrows with well-preserved oak-log coffins. Antiquity, vol. 75, nr. 287, s. 126-136.

Jensen, S. 1998: Sammenfatning. I: S. Jensen (red.): Marsk, land og bebyggelse. Ribeegnen gennem 10.000 år. Bd. 2, katalog. Den antikvariske Samlings skriftrække bind 1: B. Jysk Arkæologisk Selskabs Skrifter XXXV, s. 17-38. Højbjerg.

Orton, C. 2000: Sampling in Archaeology. Cambridge Archaeological Manuals. Cambridge.

Petersen, P.V. 1993: Flint fra Danmarks Oldtid. København.

Rasmussen, L.W. 1998: Senneolitikum og ældre bronzealder 2400-1000 f. Kr. I: S. Jensen (red.): Marsk, land og bebyggelse. Ribeegnen gennem 10.000 år. Bd. 1, tekst. Den antikvariske Samlings skriftrække bind 1: A. Jysk Arkæologisk Selskabs Skrifter XXXV, s. 103-113. Højbjerg.

Stafford, M.D 1998: In Search of Hindsgavl: Experiments in the Production of Neolithic Danish Flint Daggers. Antiquity, vol. 72, nr. 276, s. 338-349.

Thompson, S.K. 1990: Adaptive cluster sampling. Journal of the American Statistical Association, vol. 85, s. 1050-1059.

Thompson, S.K. \& G.A.F. Seber 1996: Adaptive Sampling. New York.

Thrane, H. 1963a: Hjulgraven fra Storehøj ved Tobøl i Ribe Amt. Kuml 1962, s. 80-112.

Thrane, H. 1963b: To Egekistegrave fra Tobølegnen. Kuml 1962, s. 113-122.

Vemming-Hansen, P. \& B. Madsen 1983: Flint axe manufacture in the Neolithic. An experimental investigation of a flint axe manufacture site at Hastrup Vænget, East Zealand. Journal of Danish Archaeology, vol. 2, 1983, s. 43-59. 


\section{Barrows, Landscape and Settlement Field surveys at the Tobøl-Plougstrup barrow group}

A group of barrows located between the villages of Tobøl and Plougstrup in the parishes of Føvling and Jernved in Ribe County has on several occasions been the object of intense archaeological interest. The group consists of 26 burial mounds all situated close to or in some cases almost directly on the eroded banks of the Kongeå river meadows (fig. 1). Extraordinarily lavish grave goods together with conspicuously large mounds have contributed to an impression of an area of special significance in prehistory. It is, however, the recovery of well-preserved oak log coffins from the Early Bronze Age in three different mounds, which in particular has drawn attention to the locality. The coffins were in every case uncovered under adverse circumstances leaving only scattered information on find circumstances and grave goods.

As part of a larger research program the Tobøl-Plougstrup area was revisited in 1999 where a number of drillings were carried out in selected mounds. The aim was to obtain knowledge on prehistoric soil development, principles of barrow construction and preservation of organic matter in the mounds. In the core of several mounds the presence of an iron pan encapsulation was detected. These iron pans facilitate the preservation of organic matter and have been observed in connection with almost all discoveries of oak log coffins. Recent investigations suggest that the iron pans have developed because of special constructionmethods. This has added to the impression of the special role of the barrow group. In the period 2002-2004 the five metre-high Skelhøj mound will be excavated. With an iron pan encapsulated core the excavation opens the possibility of improved insights into a variety of aspects of Early Bronze Age society. Furthermore, soil analyses of sod material from the other mounds throw light on long-term cultural exploitation of the areas in the vicinity of the individual mounds.

Existing information on Late Neolithic and Early Bronze Age finds suggests that settlement was restricted to the southern side of the Kongeån, opposite the mounds (fig. 1). This leaves an impression of a secluded ritual landscape on the northern banks of the river.

Focusing on the overall role of mound building and its effect on the development of settlement and landscape it was decided to carry out a systematic field survey of the area. The applied survey strategy had to enable studies of both regular occupation sites and patterns of "off-site" land use. Based on this demand and a wish to preserve the compatibility of the collected material it was decided to apply a strategy of adaptive cluster sampling.

Adaptive cluster sampling is a recently developed statistical sampling procedure intended for clustered populations. It is based upon an initial randomised or systematic distribution of sample units in a regular grid. If a predetermined critical value is exceeded in a unit, its neighbouring units are also sampled (fig. 2). The method in this way focuses on the relatively most informative clusters of the material without losing the statistical properties. This makes it well suited for archaeological field surveying.

In practice, the sampling at Tobøl-Plougstrup started out with a systematic grid of $20 \times 20 \mathrm{~m}$ squares in which every 9th square was initially subjected to a $20 \mathrm{~min}$. single person survey. The total sample area covers five square kilometres (fig. 3). It was decided to collect all artefacts, estimated to be more than 200 years old. If a square exceeded a critical value of artefacts four of the adjacent squares were surveyed. The method proved 
very effective for sampling and delimiting, even in connection with small concentrations of cultural remains (fig. 4). Information on all collected material is contained in a digital database (fig. 5 gives a schematic description of the database in Danish).

The survey is still preliminary and the results should be treated accordingly. However, some overall tendencies are observed. The distribution of four chronologically significant categories of ceramics reveals tempospatial patterning (fig. 6). Flint of good quality is very scarce in the area, which is reflected in several aspects of the flint assemblage, for instance the size and exploitation of the cores (fig 7). As regards the production of larger tools like thin-butted flint axes, only the last stages of reduction are present suggesting that these implements entered the area almost completed (fig. 8). The distribution of formal flint tools is to a large extent in accordance with the distribution of ceramics. Two early/ Neolithic/early middle Neolitihic concentrations on the southern side of the Kongeå stand out in particular (fig. 9). Bifacial tools from Late Neolithic and Early Bronze Age are found primarily at three different locations. In the central part of the barrow group, between two concentrations of barrows, some scattered finds of bifacial tools are present (fig. 10). This distribution of finds is compared to the evidence of prehistoric soil development as attested by the drillings in the mounds. Based on this comparison a zoning of the landscape exploitation is hypothesised (fig 11).

In conclusion, as regards methodology, adaptive cluster sampling has been quite manageable in the field and must be recognised as a preferable alternative to conventional sampling and surveying. A survey of the remaining part of the Tobøl-Plougstrup area is to be carried out in the near future.

Steffen Terp Laursen Kasper Lambert Johansen Mads Kähler Holst

Department of Prehistoric Archaeology, University of Aarhus Moesgård

Marianne Rasmussen Historical-Archaeological Research Centre, Lejre. 